\title{
Conteúdos culturais do telejornalismo e a presença das mulheres jornalistas
}

\author{
Ana Carolina Rocha Pessôa Temer ${ }^{1}$ e Mônica Rodrigues Nunes²
}

$\overline{1}$ Professora e pesquisadora do Programa de Pós-graduação da Faculdade de Informação e Comunicação da Universidade Federal de Goiás (FIC-UFG). Pós-doutora pela Universidade Federal do Rio de Janeiro (UFRJ). Doutora e mestre em Comunicação Social pela Universidade Metodista de São Paulo. anacarolina.temer@gmail.com. da Universidade de São Paulo (ECA/USP). Jornalista, mestre (2003) e doutora (2007) em Comunicação Social pela Universidade Metodista de São Paulo. mrnunes@usp.br. 


\section{Resumo}

Palavras-chave

Este trabalho aborda a notícia cultural (informações sobre cultura) veiculada em três telejornais matinais de emissoras de sinal aberto brasileiras: Fala Brasil (Rede Record), Notícias da manhã (SBT) e Bom dia Brasil (Rede Globo). Trata-se de um estudo comparativo que parte do desenvolvimento histórico do jornalismo cultural e do jornalismo feminino no Brasil para enfocar as características da cobertura de notícias culturais e os critérios utilizados para a seleção das mesmas no telejornalismo contemporâneo. Como elemento complementar, analisamos o papel de mulheres profissionais de telejornalismo na veiculação de assuntos ligados à cultura. Nesse sentido, pretende-se um debate sobre o jornalismo cultural, sua presença no telejornalismo e a presença da mulher jornalista no telejornalismo.

Jornalismo cultural, telejornalismo, mulheres jornalistas, critérios de noticiabilidade.

\section{Abstract}

The present works studies television news on culture as seen on three morning time news shows broadcasted by open signal channels: Fala Brasil (Speak up Brazil/Rede Record), Notícias da manhã (Morning news/SBT) and Bom dia Brasil (Good morning Brazil/Rede Globo). We perform a comparative analysis going from the history of the development of both cultural and feminine journalism in the country to focus on the particularities of the news coverage on culture and the criteria used for such news selection in contemporary journalism. As an additional perspective to the study, we analyze the role of professional female journalists working with cultural news coverage. In that sense, we intend to debate on cultural journalism, its overall presence in television news and also the presence of women journalists on it.

\section{Keywords}

Cultural journalism, television news, women journalists, news criteria. 


\section{Jornalismo cultural}

A capacidade do ser humano de adquirir, processar e compartilhar informações foi fundamental para o desenvolvimento do homem, tanto no que diz respeito à sua organização social e política, quanto às suas manifestações culturais. Essa capacidade de se comunicar, que se desenvolve em diferentes formas e conteúdos, ganhou novas e complexas relações na sociedade industrial moderna. Nesse ambiente, a marca é a presença dos meios de difusão de informação e de comunicação eletroeletrônicos, que replicam/reproduzem conteúdos em larga escala. A informação perdeu as características aleatórias que determinavam a circulação de uma notícia ou um boato na praça pública e passou a ser concebida a partir de uma produção planejada e artificialmente acelerada, em muitos aspectos semelhante à dos demais produtos industrializados e orientados em função do mercado consumidor.

Os novos processos produtivos impostos pelas mídias alteram não apenas a quantidade de informações que chegam ao grande público, como também a qualidade dessa informação: na sociedade industrializada moderna as dinâmicas sociais englobam complexas relações com a mídia e com os limites impostos pela produção industrializada da informação.

Nesse aspecto, a "produção" do material jornalístico é exemplar. Ainda que o senso comum aponte para a noção de que o jornal é o espaço da notícia, do que é essencialmente novo e não conhecido nos dias anteriores ${ }^{3}$, a própria concepção de que é preciso "produzir" para cada novo exemplar um material "novo", exige a implantação de complexas estratégias para a obtenção de informações sempre inéditas (ou aparentemente inéditas) e significativas para o leitor/receptor. As rotinas de trabalho desenvolvidas pelos jornalistas visam não apenas garantir que fatos importantes estejam presentes nas manchetes jornalísticas, como também seduzir o receptor.

$3 \quad$ Ainda que o termo jornal seja aplicável a veículos de diferentes periodicidades, a origem da palavra remonta a ideia de "jornada" ou de um ciclo diário completo, o que justifica a referência citada. 
Outro ponto significativo é que a diversificação dos veículos e a segmentação do público abriram espaços para novos temas, assuntos, possibilidades, enfim, novos conteúdos destinados a novos segmentos do público.

Neste contexto de múltiplos temas e enfoques, a cultura, como parte do caráter humano e um elemento essencial para a vida social, não foi ignorada. A imprensa, primeiro por meio dos jornais impressos e posteriormente do rádio e da televisão, abriga espaços específicos para divulgar produtos culturais, tanto na íntegra quanto através de anúncios, notícias e análises destes produtos. Os modernos jornais diários e as emissoras de televisão ratificam esse princípio através dos cadernos de cultura ou dos programas destinados a comentar, mostrar e analisar cultura.

Considerados estes aspectos, a proposta desse artigo é uma discussão sobre a evolução do jornalismo cultural, visando debater o espaço que conquistou no interior de diferentes mídias, seus vínculos com o jornalismo feminino ou destinado ao público feminino, ou, ainda, com mulheres jornalistas, através da análise de três telejornais matinais: Bom dia Brasil (Rede Globo), Fala Brasil (Rede Record), Notícias da manhã (SBT).

\section{Jornalismo cultural e jornalismo feminino: jornal e televisão}

Nos dias atuais, os custos e as características da produção jornalística tornaram indispensáveis a determinados setores da indústria da informação ampliar e fidelizar os anunciantes e o seu público.

Neste conjunto, o jornalismo especializado funciona como uma resposta à necessidade destes grupos ou audiência específica por informações direcionadas e/ou especializadas. A criação desses espaços também abriu possibilidades para experimentações de linguagens e até para a introdução de novas rotinas de produção e novas formas de elaborar pautas jornalísticas. Nesse contexto, o jornalismo cultural e o jornalismo feminino, ou impressa feminina, muitas vezes se encontraram compondo cadernos "especializados", nos quais os assuntos ligados ao dia a dia da mulher, e particularmente da dona de casa, misturavam-se às resenhas e às críticas teatrais, compondo o chamado estilo magazine (VILAS BOAS, 1996). 
Nos jornais diários brasileiros, a proximidade entre os temas literários e/ou culturais e os temas femininos, em diferentes momentos, foram bastante evidentes. Em cadernos ou suplementos voltados para o público feminino, em geral de periodicidade semanal, a publicação de poemas, sonetos, contos e outros gêneros literários eram muito frequentes, sobretudo na primeira metade do século XX. A autoria das produções literárias se mesclava entre senhoras do lar e autores consagrados ou estreantes.

Entre outros exemplos da proximidade entre imprensa cultural/literária e feminina, podemos citar os suplementos culturais, também intitulados "suplementos literários", publicados na imprensa brasileira entre as décadas de 1920 e 1970. Essas publicações editavam, além de matérias sobre o universo cultural e produções literárias, conteúdos muito específicos do universo feminino, como: culinária, comportamento, beleza e moda. Na imprensa paulistana, há muitos exemplos desta característica dos suplementos literários ${ }^{4}$. Destacamos o suplemento Nas letras, nas artes e no lar e na sociedade, lançado em dezembro de 1958 no jornal Correio paulistano. Composto por oito páginas, metade delas era dedicada aos assuntos literários e culturais e, outra metade, aos assuntos femininos.

Outros suplementos literários da imprensa paulistana também editavam seções ou páginas para os assuntos femininos, entre eles: o Supplemento da Folha da manhã, que a partir de 1937 passou a publicar a página Elegância e conforto; o Suplemento literário do Diário de S. Paulo, que desde o seu lançamento publicava na página 3 a seção Mulher, criança e lar; e o suplemento Pensamento e arte do Correio paulistano que, em 1953, passou a publicar a Página feminina.

Outro suporte do jornalismo cultural que já teve bastante proximidade com jornalismo feminino é o caderno diário de cultura. No Brasil, estas publicações surgiram na década de 1950, tendo tornado uma prática comum, nos jornais diários, a partir dos anos de 1980.

Um dos primeiros cadernos diários voltados para o universo cultural de nossa imprensa foi a Folha ilustrada publicada pelos jornais Folha da noite e 
Folha da tarde (a partir de 1960, apenas Folha de S. Paulo). E segundo Cassiano Eleck Machado, este caderno foi criado para atender o público feminino: "José Nabantino tinha a ideia de que o primeiro caderno ficaria com o marido e, o segundo, a Ilustrada, com a mulher" (2001, p.18).

Até a década de 1970, quando o caderno teve seu nome alterado apenas para Ilustrada, seu conteúdo não se detinha como observador exclusivo de temas culturais. Matérias sobre beleza, artes, literatura, moda, turismo, ciências, fofocas, rádio, televisão, horóscopo, saúde, entre outras, compunham seu noticiário.

Na contramão desta segmentação dos cadernos culturais, atualmente muitos jornais preferem publicar cadernos de conteúdos mais abrangentes, em geral, intitulados de cadernos de variedades. Estes têm por característica publicar um leque maior de assuntos - artes, espetáculos, beleza, diversão, curiosidades etc. -, não se restringindo apenas aos temas normalmente encontrados em um caderno cultural. São muitas vezes recheados de matérias relacionadas ao universo feminino.

Se, nos jornais, o espaço dedicado às notícias sobre artes e espetáculos foi crescente, na televisão, não podemos afirmar o mesmo. Certamente, se houve um momento em que o assunto cultural foi destaque em sua programação, foi àquele relacionado aos primeiros anos de transmissões no Brasil. Nesse período, a televisão ainda não era um veículo de grande alcance e, o aparelho, um objeto que poucos podiam comprar. Segundo Reimão, "a programação da televisão brasileira em seus primeiros anos é considerada sendo 'elitista': teatro clássico e de vanguarda, música popular e erudita e alguns poucos shows mais populares" (2006. p. 25).

As tecnologias de veiculação e produção televisiva e o barateamento do aparelho televisor permitiram que a televisão se tornasse um veículo mais presente nos lares brasileiros, potencializaram a busca por audiência e lucro, o que alterou o perfil da programação das emissoras. O assunto cultural foi, aos poucos, dando lugar a programas de conteúdos mais populares e, eventualmente, até grotescos. 
Com maior ou menor força, essa é uma tendência que permanece e, neste início de século, a maioria das redes de televisão brasileiras têm dedicado pouco espaço ao jornalismo cultural. Como veremos mais adiante, os telejornais dos canais abertos de televisão quase não abordam o tema cultural em suas edições. Eventualmente, matérias mais leves (incluindo aquelas relacionadas à arte e ao espetáculo) são utilizadas nas edições diurnas e como estratégia para o fechamento das edições ${ }^{5}$.

Um telejornal que apresenta um perfil diferenciado é o Leitura dinâmica, veiculado pela Rede TV por volta da meia noite, que apresenta, além do hard news, matérias relacionadas a artes e a espetáculos - uma agenda cultural das grandes capitais do País. Ressaltemos que, para os assuntos culturais, as matérias são dadas de forma breve, por meio de notas cobertas, sem qualquer apelo crítico. Incluir uma breve agenda cultural nas edições de sexta-feira também tem sido uma estratégia utilizada pelos telejornais locais do meio do dia, veiculados pela Rede Globo e pelas suas emissoras afiliadas.

Entre os poucos programas voltados exclusivamente para a cobertura de artes e espetáculos nas emissoras de sinal aberto brasileiras está o semanal Moisaico bahiano, veiculado pela Rede Bahia de Televisão e TV Salvador, às $14 \mathrm{~h} 45$ e às $19 \mathrm{~h} 15$, respectivamente.

No ar desde julho de 2007, o programa estreou em sete de julho de 2007, é caracterizado por seus idealizadores como uma revista eletrônica sobre "curiosidades, clipes, documentários, séries especiais, dicas de cinema, teatro, shows, artistas, visitas aos bairros, comportamento, turismo, cobertura de eventos da cidade [Salvador]"6. O programa também visa ser um espelho dos acontecimentos culturais da Bahia.

Com exceção de alguns poucos programas editados por televisões de sinal aberto, verificamos que os programas de jornalismo cultural aparecem com maior regularidade nas televisões educativas. Revistas eletrônicas sobre

$\overline{5}$ Sobre essa questão, ver TEMER (2002).

6 http://ibahia.globo.com/mosaico/default.asp 
artes e espetáculos estão presentes em várias delas. Atualmente estão no ar as revistas eletrônicas culturais: programa Agenda, da Rede Minas, desde 1987, com edições de segunda-feira a sábado; programa metrópolis, da TV Cultura, desde 1988, veiculado de segunda a sexta-feira; Estação cultura, da TVE/RS (Fundação Cultural Piratini), de segunda a sexta-feira; programa $R e$ [corte] cultural, da TVE/Rio, também com edições de segunda a sexta-feira e reprises aos domingos, e programa Soterópolis, da TVE Bahia, com edições às quartasfeiras e reprises às quintas-feiras e aos domingos.

Outro diferencial das televisões educativas é a veiculação de programas especializados, voltados para temas como literatura, música, cinema, teatro, etc. A periodicidade destes programas é variável tendo, em média, duas edições por semana (inéditas ou reprises). Programas semelhantes são encontrados em canais de televisão por assinatura. Um exemplo está na Globo News, que transmite diversos programas, entre eles: Start, GloboNews Documentário e GloboNews Literatura.

Embora os programas de televisão voltados unicamente para o jornalismo cultural sejam poucos, o mesmo não pode ser dito sobre os programas voltados para o público feminino. De fato, ao mesmo tempo em que as revistas femininas se sofisticavam com títulos como Cláudia7, o modelo era copiado pela televisão, que usava as fórmulas consagradas pelas revistas para veicular assuntos destinados ao público feminino. Ao mesmo tempo, a televisão impunha sua condição de veículo de maior prestígio entre os anunciantes.

Considerando os aspectos históricos, "desde os primórdios, a TV Tupi de São Paulo produziu programas dirigidos à mulher, especialmente à dona de Casa" (RIXA, 2000, p. 156). O modelo "culinária e variedades culturais com diferentes apresentadoras" sempre teve relativo sucesso e boa aceitação entre o público feminino, até que, na década de 1980, a Rede Globo lançou o TV mulher, uma versão esteticamente mais elaborada com conteúdo diferenciado que incluía desde informações culturais até orientação sobre sexo e educação. O TV mulher proporcionou um grande impacto sobre o gênero, mas, na década de 1990, o 7 A revista Cláudia se destaca por ter reportagens mais elaboradas e, principalmente, pelo amplo uso de ilustrações e 
modelo sofreu uma nova mudança com o Note e anote. Sua proposta fez tanto sucesso que sua condutora, a apresentadora Ana Maria Braga, foi convidada a transferir-se com um alto salário para a Rede Globo.

O sucesso do modelo Note e anote deu origem a uma profusão de programas do mesmo estilo, quase sempre apoiados no tripé "culinária, artesanato e comportamento"8, em programas presentes na grade de programação de diversas emissoras, em versões matinais ou vespertinas. Esses programas abrem espaço, também, para a divulgação de artistas de todos os tipos, desde o lançamento de discos, literatura e outros tipos de arte e artesanatos, além de entrevistas com diversos tipos de profissionais ligados ao mundo do espetáculo e com personagens que, por qualquer motivo, estejam momentaneamente em evidência.

\section{A cultura e o jornalismo "feminino"}

Para entendermos a relação entre a presença da mulher jornalista na cobertura dos assuntos relacionados à cultura, é preciso também fazer uma análise do conceito de cultura. Embora alguns setores vinculem o termo à ideia da cultura de elite - das obras literárias clássicas e dos grandes espetáculos de ópera - na verdade, a "cultura não é a prática, nem simplesmente a descrição da soma dos hábitos de uma sociedade. Passa por todas as práticas sociais e suas inter-relações" (HALL apud WOLF, 1987, p.94).

Ou seja, cultura é tudo aquilo que fazemos, vestimos, comemos, produzimos. Nesse sentido, os veículos destinados ao público feminino são um grande espaço para representações culturais diversas, uma megavitrine esteticamente manipulada das culturas desejadas ou desejáveis para os públicos que se pretende atingir.

Nas sociedades capitalistas industrializadas, as revistas femininas muitas vezes se encarregam de fornecer dados importantes para entendermos a cultura de um determinado grupo social ou da sociedade na qual ele circula. No entanto, uma vez que os meios não são neutros, pois se colocam entre o os seus leitores 
e o mundo, aquilo que pretendem ou afirmam reproduzir torna-se um retrato, ou seja, uma parte retirada do todo. Esta, ainda mantendo uma relação de veracidade com o conjunto inicial, não representa a totalidade deste conjunto. Nesse sentido, os meios - e evidentemente, o jornalismo em diferentes meios -, influenciam os costumes (ou a cultura) e até mesmo criam uma nova forma de se compreender a própria cultura.

\section{O jornalismo cultural no telejornalismo e a presença da mulher jornalista}

O material jornalístico que aborda, diretamente ou indiretamente, o comportamento e as questões relativas à cultura tem um valor simbólico significativo para os receptores. Ele opera à maneira de um mostruário da cultura material na sociedade capitalista dependente (máquinas de lavar, de costura, automóveis, batedeiras etc.) (MICELI 1972, p. 218).

No que diz respeito à cultura, temos aí dois aspectos: o consumo da cultura em si mesma - a cultura como produto a ser consumido em espetáculos, exposições, etc. - ou a necessidade de informar/adaptar culturalmente o receptor, por exemplo, ensinando a roupa adequada para obter um emprego, etc.

Embora, aparentemente, este conteúdo jornalístico apresente um material de "não conflito" ou fatos-ônibus ${ }^{9}$, trata-se de conteúdo basicamente ideológico, que atuam no sentido de criar expectativas de consumo cultural. Atuam na definição de identidades sociais, mas também trabalham questões sobre o status dos receptores, ao mesmo tempo em que representam uma forma exógena de definir/difundir socialmente aspetos ideologicamente interessantes da própria cultura.

Em termos práticos, a presença da mulher jornalista na cobertura dos assuntos ligados à cultura, portanto, obedece a um duplo fator: reproduz, ainda que de forma distanciada e indireta, o seu papel de "mãe-condutora" dos infantes no adentramento ao mundo cultural e social, mas também afasta a mulher jornalista da cobertura factual, política e econômica, aspectos

9 Termo utilizado por Bourdieu, para quem "Os fatos-ônibus são fatos que não envolvem disputa, que não dividem, que formam consenso, que interessam a todo mundo, mas de um modo tal que não tocam em nada de importante" (BOURDIEU, 1997, p. 23). 
apresentados como mais importantes, mais perigosos, ou que atribuem maior status à prática profissional.

No entanto, ainda que se possa trabalhar com a hipótese de que este posicionamento permaneça, o jornalismo possui um vínculo inexorável com o cotidiano: jornalismo é vida, e muda assim como muda a sociedade. Torna-se importante, portanto, averiguar até que ponto estes vínculos permanecem e como eles são expostos nos telejornais matinais, que tradicionalmente captam uma maior atenção do público feminino ou são elaborados em função deste público.

\section{Sobre os telejornais analisados}

A análise dos dados teve como base a gravação e acompanhamento dos programas veiculados na semana de 18 a 22 de agosto de 2014. Foram analisados três telejornais, sendo cinco edições de cada um deles: Notícias da manhã (SBT), Fala Brasil (Rede Record) e Bom dia Brasil (Rede Globo). A baixa presença de matérias sobre cultura obrigou as pesquisadoras a trabalharem também, de forma comparativa, com as principais notícias da semana, buscando justificativas para a ausência deste material.

Dos três telejornais, Notícias da manhã (SBT) é o mais jovem deles. Apresentado por César Filho e Patrícia Rocha, de segunda à sexta-feira, das 7h às 9h, o programa estreou em 09 de junho de 2014 e entrou na grade de programação do SBT para substituir o telejornal SBT $2^{\circ}$ Edição.

Notícias da manhã é dividido em duas seções, na primeira hora de transmissão (das $7 \mathrm{~h}$ às $8 \mathrm{~h}$ ) o sinal é aberto apenas para o estado de São Paulo ${ }^{10}$, na segunda hora (das $8 \mathrm{~h}$ às $9 \mathrm{~h}$ ), o sinal é aberto para todo o país. Por esta característica, a maioria das notícias transmitidas na primeira hora é sobre o estado de São Paulo, o que não excluiu reportagens e entradas ao vivo vindas de outros estados da federação e do Distrito Federal, sobretudo em situações de coberturas mais urgentes.

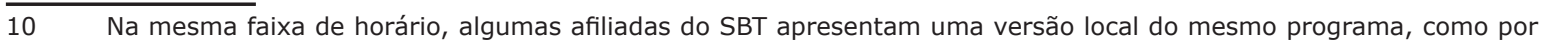
exemplo, SBT Rio Grande manhã, no Rio Grande do Sul, e SBT Rio manhã, no Rio de Janeiro. 
O programa é constituído de reportagens especiais, previsão do tempo, informações sobre o trânsito e atualização das últimas notícias com imagens feitas por helicóptero (estas duas apenas na primeira hora), participação dos correspondentes internacionais, comentaristas (na semana analisada, apenas esportivo, Bruno Vicari) e entrevista no estúdio. Na semana estudada a entrevista foi com um vidente que disse ter previsto a queda do avião que matou o candidato à eleição presidencial Eduardo Campos. A partir das oito horas, ao abrir o sinal para todo o Brasil, o enfoque passa a ser a cobertura das principais notícias do Brasil e do mundo. Apresentadores das afiliadas do SBT e repórteres de todo o país fazem entradas ao vivo, apresentando cabeças das matérias ou links das últimas notícias ou a repercussão de fatos.

Nas edições do Notícias da manhã há busca de interatividade com os telespectadores através das mídias sociais, com o uso da hashtag \# noticiasdamanhã. Na semana analisada, um concurso com imagens do nascer do sol foi lançado. Os telespectadores deveriam enviar uma foto usando a hashtag \# noticiasdamanhã e um clipe com as cinco melhores imagens foram publicadas no encerramento da edição de sexta-feira (22/08). Além disso, em cada edição há uma enquete sobre assuntos de destaque. Mensagens de telespectadores são lidas durante a transmissão do telejornal.

Outro telejornal estudado, Fala Brasil (Rede Record), em sua origem era pouco parecido com o atual formato. Ao ser criado, em 1990, seu conteúdo era muito próximo do programa Hoje em dia da mesma emissora. Dez anos depois o programa assumiu o formato atual, ou seja, de telejornal. Transmitido de segunda-feira a sábado, sua apresentação é realizada por duas mulheres: Carla Cecato e Roberta Pizza.

Transmitido das $8 \mathrm{~h} 45$ às $10 \mathrm{~h}$ com sinal aberto para todo o país, uma das características do Fala Brasil é o grande número de matérias no formato de nota coberta, sobretudo para assuntos internacionais, e de entradas ao vivo de repórteres do Distrito Federal e de diversos estados brasileiros. Reportagens realizadas no Brasil e no exterior também são transmitidas. Outra característica 
do programa é o forte apelo para notícias que envolvam situações curiosas da vida de celebridades, com destaque nas escaladas e passagens de bloco, transmitidas, em muitas edições, no encerramento dos telejornais.

Em geral, as notícias - reportagens e notas cobertas - do mundo esportivo são apresentadas por Salcy Lima. Embora haja interação entre as apresentadoras Carla Cecato e Roberta Pizza com Salcy, a apresentação do noticiário esportivo é feita em outro estúdio da Rede Record.

O mais antigo dos três telejornais analisados, Bom dia Brasil, da Rede Globo, estreou em 1983. Apresentado por Carlos Monforte, este telejornal era transmitido diretamente de Brasília, com duração de trinta minutos. Seu conteúdo era essencialmente político e econômico. Na década de 1990, ele foi reformulado visualmente, com um novo estúdio e bancada para os apresentadores, passou a ter duração de uma hora e abriu espaço para novas editorias com entradas ao vivo vindas de diversas capitais do país.

Atualmente, o Bom dia Brasil é apresentado por Chico Pinheiro e Ana Paula Araújo e conta com um correspondente em Londres, Renato Machado, comentarista de notícias internacionais, além de correspondentes nos Estados Unidos, Japão, Londres, Portugal, entre outros. Renata Lo Prete, Miriam Leitão e Alexandre Garcia reforçam o time de comentaristas do telejornal. Durante a transmissão do Bom dia Brasil, que acontece das 7h30 às 8h40, há a participação das praças de São Paulo, com a apresentação de Rodrigo Boccardi, que apresenta notícias do estado, e de Brasília, com a participação de Giuliana Morrone, que comenta e apresenta as notícias do Distrito Federal com enfoque para a cobertura política, além de um quadro de notícias esportivas apresentado por Luís Ernesto Lacombe.

Neste telejornal, não há um formato jornalístico predominante, incluindo apresentação de reportagens, de notas cobertas, de notas secas e de entradas ao vivo dos estúdios de São Paulo e Brasília e entradas ao vivo de repórteres de todas as regiões do país. 


\section{Cinco edições e pouca cultura}

Como já dito, no período de 18 a 24 de agosto de 2014, cinco edições dos telejornais Notícias da manhã (SBT), Fala Brasil (Rede Record) e Bom dia Brasil (Rede Globo) foram gravadas na íntegra para a realização da análise.

A partir do levantamento de todo o conteúdo jornalístico dos três telejornais, verificou-se algumas características comuns entre eles. A primeira delas é a busca por uma cobertura que contemple todo o país, que acontece através do recebimento de material jornalístico das praças ou afiliadas e das entradas ao vivo de apresentadores ou repórteres. Outra característica é o uso de espaço para fazer autopromoção de programas ou projetos, jornalísticos ou não, das emissoras a que pertencem os telejornais. Percebe-se também, em maior ou menor grau, que todos os apresentadores fazem comentários pessoais sobre os fatos noticiados. No caso específico do Notícias da manhã, o tempo utilizado para os comentários de César Filho é, muitas vezes, superior ao dispensado à transmissão da notícia. O material genuinamente opinativo é realizado por comentaristas/especialistas, com maior frequência no Bom dia Brasil. E, por fim, como se verá mais adiante, não há preocupação em priorizar espaço, dentro dos telejornais, para noticiar fatos voltados ao âmbito cultural.

Após levantamento das matérias transmitidas pelos três telejornais, selecionamos as de conteúdo cultural. Dentro deste perfil, o telejornal que mais abordou o tema foi o Notícias da manhã. No entanto, a maioria das informações com vínculo à cultura privilegiou questões ligadas a eventos pontuais, como uma reportagem sobre o aniversário de 60 anos do Parque Ibirapuera, da capital paulista, em 21 de agosto de 2014. Houve destaque para as atrações culturais como, por exemplo, a programação do Museu de Arte Moderna, e três entradas ao vivo sobre o mesmo tema, com enfoque para os painéis "Viva o Ibirapuera", feitos especialmente para a data comemorativa pelo artista plástico Eduardo Kobra. Ainda no dia 21 de agosto, no quadro "Comida de Rua", foram realizadas duas entradas ao vivo e uma reportagem sobre o festival gastronômico Sanduweek. 
A Bienal Internacional do Livro de São Paulo ${ }^{11}$, no dia de abertura do evento, 22 de agosto de 2014, foi noticiada com duas entradas ao vivo. Nesse mesmo dia, no final do primeiro bloco, foi apresentada a agenda cultural das atrações musicais com apresentações na capital e Grande São Paulo e uma nota coberta sobre uma curiosidade do Museu do Louvre. Ele teve, em 22 de agosto de 1911, uma das suas principais obras roubadas, o quadro da Monalisa de Leonardo da Vinci.

O telejornal Bom dia Brasil (Rede Globo), em princípio considerado o mais elitizado do horário, não apresentou notícias sobre cultura. Ainda assim, a emissora não ignorou o aniversário do parque Ibirapuera, mas o enfoque adotado foi sobre "andar de bicicleta no parque", com link ao vivo.

No telejornal Fala Brasil (Rede Record), o mundo das celebridades é o grande enfoque. Nesse sentido, o relevante passa a ser a intimidade delas e de seus familiares, em geral, em situações negativas. Como por exemplo, a separação de Maria Carey e Nick Cannon, Brigitte Bardot andando de muletas e atriz Julia Lemmertz que se recusou a fazer o teste do bafômetro e teve a carteira de motorista apreendida. Problemas de saúde, ocorrências policiais e morte de artistas também ganham destaque no noticiário, como as entradas ao vivo com informações sobre o estado de saúde da atriz Aracy Balabanian e a agressão sofrida pelos cantores Matheus e Kauan em assalto na cidade de Prata, em Minas Gerais, além da nota coberta sobre a morte da bailarina Mercedes Batista. Assim, quando se trata de assuntos culturais, no Fala Brasil, os valores-notícia de seleção estão no que Traquinas (2008, p. 79) chama de critérios substantivos, como a morte, demonstrando o negativismo do mundo jornalístico, e a notoriedade do ator principal do acontecimento. Nesse caso, não se trata da notoriedade das obras e eventos culturais, mas a notoriedade de pessoas ligadas ao mundo artístico.

O levantamento dos assuntos noticiados pelos três telejornais permite-nos afirmar que, em todos eles, não há espaço regular dedicado à informação cultural. Isso, ao contrário de esportes, economia, política e informações internacionais, que têm espaço garantido nas edições dos telejornais.

11 Este evento ocorreu de 22 a 31 de agosto de 2014, com extensa programação cultural e a participação de editoras nacionais e internacionais com a apresentação de lançamentos editoriais. 
O baixo índice de matérias voltadas à informação cultural pode, também, na semana analisada, ter ocorrido em razão da repercussão de assuntos ${ }^{12}$ mais urgentes, como: a falta de água em diversas regiões do país, com ampla cobertura, inclusive com giro de entradas ao vivo de repórteres atualizando a situação da água em seus estados; o enterro de Eduardo Campos e a investigação sobre as causas do acidente com o avião; a definição do novo candidato à eleição do PSB; o dia dos principais candidatos à eleição; adulteração do leite em Santa Catarina; a prisão do médico Roger Abdelmassih; o relaxamento da prisão de Suzanne von Richthofen; os protestos nos EUA pela morte de uma jovem negro por um policial branco; os conflitos em Gaza; o surto de ebola; a greve na Universidade de São Paulo (USP); e a briga entre torcedores do Palmeiras e Corinthians que resultou na morte de um torcedor palmeirense.

A maior parte das matérias sobre informação cultural teve a presença da mulher jornalista na condição de repórter. No entanto, o baixo índice de matérias sobre cultura não permite uma conclusão segura neste ponto. Como opção metodológica, buscou-se uma comparação da presença feminina no jornalismo cultural com a mesma presença nos principais assuntos da semana citados anteriormente.

Consideradas tais coberturas, verificou-se que a presença das repórteres mulheres é majoritária, superando o dobro do número de repórteres do sexo masculino. Essa relação, por si só significativa, reflete a feminização da profissão, aspecto que já é visível nos cursos de jornalismo. Nesse sentido, ainda que a presença feminina seja percentualmente maior nos assuntos culturais, ela é também um reflexo cada vez mais visível da presença das mulheres nas redações de telejornalismo.

No entanto, ainda que de forma preliminar, a análise dessa relação mostra que o vínculo da mulher jornalista com a cobertura dos temas ligados à cultura permanece, e ainda tende a ser maior do que a presença feminina em outras coberturas. É digno de nota, também, a percepção de que a produção dos temas ligados à cultura ainda é pouco valorizada. A inconsistência das pautas/coberturas 12 A seleção dos assuntos foi realizada em função da repetição, presença nos telejornais e quantidade do tempo dedicado 
presentes na semana analisada reflete um sentimento não verbalizado pelos editores de que se trata de um tema menor, ou menos importante. E havendo necessidade de retirar do espelho algum conteúdo para dar espaço para assunto mais urgente, a notícia cultural - por mais elaborado que esteja o material está entre as primeiras a ser descartada.

Outro elemento importante, e igualmente significativo, está na diluição da cobertura de assuntos culturais na exposição do mundo das celebridades, que é o ponto principal do telejornal Fala Brasil, da Rede Record. Trata-se de uma cobertura centrada em celebridades do momento, ou quase celebridades, uma multidão de celetóides ${ }^{13}$, cuja maior qualidade, ou o que justifica a sua presença nos telejornais, é estar na mídia. Ou seja, indivíduos cuja importância não está na participação em atividades culturais ou em si mesmos, mas na exposição em veículos midiáticos. Esse processo, de muitas formas, se reveste de uma retroalimentação da mídia por ela mesma. Dessa forma, embora se trate de uma cobertura de assuntos culturais, ela se dá por meio de um viés específico. Ao mesmo tempo em que a insere na questão da cultura, também a afasta, ou até mesmo compete, com uma cobertura voltada para a oferta, análise e exposição de produtos culturais que possam efetivamente oferecer opções para os receptores. Assim, ao invés de oferecer uma cobertura que permita ao receptor vivenciar atividades culturais, o telejornal oferece a vivência/identificação das pessoas comuns com essas celebridades de ocasião, ou seja, oferece a ilusão de uma fama possível, embora fugaz.

$\overline{13 \quad \text { Rojek (2008) }}$ aponta três tipos ou possibilidades de o indivíduo se tornar célebre, classificando a celebridade como "conferida" - aquela que deriva de algum atributo especial, como a linhagem (os membros da realeza, por exemplo); a "adquirida", que deriva das ações dos indivíduos (os grandes atletas, por exemplo); e a "atribuída", resultante de um trabalho de exposição, de representação. Nesta última estaria uma subcategoria, os celetóides, que são celebridades rápidas, de curta duração. 


\section{O foi mostrado e o que não foi mostrado: conclusões e sugestões}

A percepção de como o espaço para o jornalismo cultural na televisão se insere dentro do telejornalismo exige a compreensão de uma nova concepção de cultura, na qual a cultura mediática ou os seus produtos culturais ocupam um espaço fundamental. Nesse sentido, percebe-se que, no telejornalismo, a cultura engloba aquilo que convencionamos chamar de "comportamento humano", curiosidades da vida das celebridades reais e de ocasião, e informações pontuais sobre atividades culturais.

De muitas formas, é uma contribuição importante. O telejornalismo não apenas possibilita representações da cultura, como também o faz de uma forma plural, permitindo abordagens de diferentes modelos e de escolhas individuais, de engajamento ou de negação dos modelos propostos pela coletividade e de especificidades de públicos diferenciados. No entanto, ainda se trata de um espaço subutilizado e, eventualmente, utilizado de forma inadequada, onde predomina a cobertura voltada para a conquista fácil da audiência em detrimento do papel de prestador de serviços e veículo transmissor da herança cultural que poderia (e deveria) ser assumido pelo telejornal.

É importante destacar também que, nestes tempos de desintegração, de ruptura com um projeto de jornalismo engajado, o telejornalismo aponta para uma mudança dos paradigmas no jornalismo cultural. O que temos, agora, é a definição de um novo papel para este tipo de jornalismo "pontual", que assume o papel de divulgar eventos e informações rápidas, que tem pouco impacto na mudança do comportamento do receptor.

No que diz respeito a reflexões teóricas, é preciso considerar também se esse modelo de jornalismo responde a limites impostos pelo telespectador brasileiro, que se afastou das culturas tradicionais em função de uma migração desordenadas para os grandes centros, sem necessariamente se aproximar de uma cultura acadêmica.

Outro ponto de questionamento é se, em uma sociedade definida cada vez mais pelo vínculo da cidadania com o consumo, o telejornalismo apresenta os conteúdos culturais como algo mais a ser consumido e descartado. 
Essa reflexão encontra um novo eco no questionamento sobre a possibilidade do telejornalismo assumir a vanguarda na "explicação" dos fenômenos culturais importantes, como por exemplo, o processo de mundialização na/da cultura. Isso sem se esquecer das reações representadas pelas culturas regionais ou marginalizadas, que explodem e buscam afirmação nessa conjuntura, e de seus elementos distintos, como as lutas étnicas e as modas alternativas em suas diversas representações culturais (música, artes, etc.).

Como elemento final, destaca-se a proposta de um novo jornalismo cultural, organizado segundo a ótica da produção de informações que realmente possam servir a audiências ao mesmo tempo segmentadas e unidas por um contexto de mundialização. São esses novos parâmetros que, aliados aos fatores anteriores, devem provocar as novas reflexões no campo do jornalismo cultural. 


\section{Referências}

BOURDIEU, P. Sobre a televisão. Rio de Janeiro, Jorge Zahar, 1997.

MACHADO, C. E. "A renovação cultural". Folha de S. Paulo. Caderno especial, Folha 80 anos. São Paulo: 18 fev. 2001, p.18.

MICELI, S. A noite da madrinha. São Paulo: Perspectivas, 1972.

NUNES, M. F. R. Paulicéia literária: páginas e suplementos literários na imprensa paulistana (1920-1964). 2007. Tese (doutorado em comunicação social). Universidade Metodista de São Paulo

REIMÃO, S. (coord.). Livros em revistas: um estudo sobre a seção de livros em revistas brasileiras de grandes tiragens. São Paulo: Faculdades Salesianas,1996.

ROJEK, C. Celebridade. Rio de Janeiro: Rocco, 2008.

RIXA. Almanaque da TV. 50 anos de memória e informação. Rio de Janeiro: Objetiva, 2000.

TEMER, A. C. R. P. Notícias e serviços nos jornais da Rede Globo. Rio de Janeiro: Sotese, 2002.

TRAQUINAS, N. Teorias do jornalismo: a tribo jornalística - uma comunidade interpretativa transnacional. Florianópolis: Insular, 2008.

VILAS BOAS, S. O estilo magazine: o texto em revista. São Paulo: Summus, 1996.

WOLF, M. Teorias da comunicação. Lisboa: Presença, 1987. 